\title{
改正特許法の概要と解説
}

\author{
角田芳末 ${ }^{1}$
}

\begin{abstract}
著者抄録 : 特許法は過去頻繁に改正がなされ, ユーザのニーズに対応してきた。今回の法改正もその 一環であり，社会のIT化に対応した改正を主眼としたものである。特許庁は，2001年1月10日以降の 出願に対して, 審査基準を改訂することで, 請求項にプログラムという記載を物の発明として記載 できるとした。今回の発明の実施規定の改正はこの点を法律的に明確化するものである。また, IT 化に対応して特許権者の利益を強く保護するために, 間接侵害規定に従来の客観的要件に加えて主 観的要件を追加する改正を行った。さらに, 審査処理促進にユーザの協力を仰ぐために先行技術文 献情報の開示を義務化する改正を行った。
\end{abstract}

キーワード : 特許法, 特許法改正, 日本特許庁, 審査基準, コンピュータ・プログラム, IT化, 実施規定, 先行技術文献情報, 開示, 間接侵害規定

\section{Outline and explanation of the revised Japan Patent Law}

\section{TSUNODA Yoshisue ${ }^{1}$}

\begin{abstract}
Author Abstract: The Japan Patent Law has been revised so often so as to meet with the needs of users. The revision this time was a part of the above situation and focused on a point corresponding to the IT progress made in our society. The Japan Patent Office decided to amend an examination criterion such that an element of a computer program specified in a claim is deemed as an invention of a product and this criterion is effective from the patent applications filed on Jan. 10, 2001. The revision in the definition of "working" of the invention in this law was to clarify this point legally. In another aspect, in order to firmly protect interests of patentees in correspondence with IT progress, a revision was made where subjective requirements to indirect infringement provisions are added to the conventional objective requirements. Further a revision was made such that it became mandatory for an applicant to make technical information or documents relating to prior art which are relevant to every patent application disclosed in its specification in order to ask users' cooperation for accelerating the patent examination process.
\end{abstract}

Key words: Japan Patent Law, patent law revision, Japan Patent Office, examination criteria, computer program, IT progress, working provision, technical information on prior art, disclosure, indirect infringement provision

\section{1. 改正の経緯}

\section{1. 技術のソフト化と保護対象の拡大}

2001年12月に出された産業構造審議会知的財産 政策部会 (以下,「審議会」と言う) の報告書「ネッ トワーク化に対応した特許法・商標法の在り方に ついて」によれば，今回の法改正の経緯を，知的

\section{1信友国際特許事務所}

（テ160-0023 東京都新宿区西新宿1-8-1 新宿ビル3F）

Tel.03(3343)5821 E-mail: tsunoda@shinyu-pat.com ${ }^{1}$ Shin-yu International Patent Firm (Shinjuku building 3F, 8-1, Nishi-shinjuku 1-chome, Shinjuku-ku, Tokyo, 160-0023)
財産を巡る環境の変化にかんがみ, 次のように説 明している。情報の交換がこれまでにない規模の 密度・範囲で行われるIT化の進展に伴い, 経済社 会のネットワーク化, デジタル化が進行している。 IT化の効果を最大限に活かすため, その特性に対 応した知的財産制度の整備が不可欠である」。

この審議会報告書が言うように，今回の特許法 改正は, 正に現在急速に進展しているIT化社会対 応の改正であると言える。そもそも特許法は，そ の歴史的な経緯から見ても, 物を中心とした発明 の保護を図る制度であった。しかし, 社会の発展 とともに産業界も物中心からソフト中心の社会へ 
と移ってきたという事実がある。特許庁は, 古く からこのような社会の変化に対応して審査基準を 改訂するなどして世の中のニーズにこたえてきた が, 一方で, 審査基準の対応だけでは権利者の権 利が本当に守りきれるのかという疑問が提示され ていた。今回の改正はこれらの要請にこたえたも のである。

\section{2. 審査基準による技術のソフト化への対応}

昨今のITブームになる以前から，世の中の技術 の大きな流れは「物からソフト」へ大きくかじが 切られてきた。このソフト化に対応するため, 特 許庁は数度にわたり審査基準の作成とその改訂を 行い, 特許法で保護できる範囲を少しずつ広げて きた。古くは1975年12月に公表された「コンピュー タ・プログラムに関する発明についての審査基準 (その1)」である。世はまさにハードウエア全盛の 時期であり，ワードプロセッサーが世に現れるは るか以前のことである。この審査基準 (その1) は, 主としてコンピュータ・プログラムに関する発明 の成立性の部分を扱ったものであるが, 特許請求 の範囲の表現形式に関しては,『プログラムの性質 とりわけその技術的思想の創作と考えられるとこ ろは「手順」にあるところから, プログラムにつ いての発明は「方法」の発明として把握すること が妥当である』と規定している。つまり，プログ ラムそれ自体はコンピュータを使う方法であると いう考え方である。

次に1980年代に入ると, 電気炊飯器などの装置 や機器にマイコンが使われ始め, その関連の特許 出願が急増するという傾向が現れる。特許庁は 1982 年12月に「マイコン運用指針」を策定し，これに よってマイコン応用技術を「装置（物）」発明とし て保護することを定めた。例えば，マイコンで電 気炊飯器の温度制御を行うような発明を特許請求 の範囲に記載する際に, マイコンの働きを機能的 な手段として記載することを認めたのである。

そして1993年7月には, 改訂審査基準が策定され る。この審査基準が改訂されたものの,この基準 では技術的思想でないものの例のひとつとして, 「コンピュータ・プログラムを記録した記録媒体」 が「音楽を録音したCD」と同列に列挙されている。 また, このとき初めて, 特定技術分野の審査基準 というものが作られ, コンピュータ・ソフトウエ ア関連発明としてどのようなものが発明になりう るのか, すなわち特許法 2 条の発明の定義に合致し たものとして認められるのかが定められた。つま
りこの改訂審査基準により, 自然法則の利用性の 要件が明確化されたのである。

1996年ごろになると,フロッピーディスクやCDROMに記録されたさまざまなプログラムが市場に 流通するようになる。しかし「方法」発明として， あるいは「物 (装置)」発明としてのプログラムの 保護では, 市場に流通するCD-ROMをおさえるこ とはできない。特許庁はこのような事態を重視し, 改訂審査基準の見直しに着手した。そして, 1997 年2月に新運用指針を発表した。この運用指針で初 めて,「コンピュータ・プログラムを記録した記録 媒体」というクレームを明細書に書くことが許さ れることとなった。1993年の改訂審査基準の一部 修正を行ったわけである。この新運用指針は1997 年4月1日から運用されることになるが, 1997年3月 31日以前の出願は補正しても「コンピュータ・プ ログラムを記録した記録媒体」というクレーム記 載は認めなかった。公平性を考慮しての産業政策 的な配慮であった。この運用はしばらく続くが, インターネットの発展がさらに問題を提起するこ とになる。

すなわちインターネットの爆発的な普及により， サーバからインターネットを介してプログラムを 直接に自分のパソコンにダウンロードして利用で きる状況になった。つまり, 記録媒体を介在させ ずにソフトウエアを流通させることがいとも簡単 にできるようになったのである。こうなると媒体 クレームで権利をとっても, ネットワークを流通 して取引されるプログラムに対して権利行使でき ない。特許庁はこのような新しい利用形態に対し ても保護できるように，さらに運用指針を改定し た審査基準の検討に入り，2000年12月28日に発表 した。これが現在の特許庁で運用されている改訂 審査基準である。この改訂審査基準では, プログ ラムクレームを認め, ビジネス関連発明を含むり フトウエア関連発明の成立性についてさらに明確 化した。ただし改訂審査基準の中で, プログラム クレームの記載を認める点に関しては, 公平性の 観点から, 媒体クレームのときの例にならって, この改訂審査基準の運用が開始される2001年1月 10 日以降の出願に対してのみとした。

\section{3. 法改正による対応}

クレームの末尾を「プログラム」と記載する「プ ログラムクレーム」を改訂審査基準で認めたこと 自体は，産業界から好意的に受けとられたが，は たしてこの審査基準で認められたプログラムクレー 
ムの特許権で, ネットワークを流通するプログラ ムに対して権利行使できるのかという懸念が一部 から表明された。特許庁が行う審査基準の説明会 でも，プログラムの特許をもって権利行使できる ように法律上明確化してほしいという強い要望が 出されている。

このような事態を受けて特許庁は, 産業構造審 議会知的財産政策部会を開催し,2001年12月に「ネッ トワーク化に対応した特許法。商標法等の在り方 について」という答申をまとめた。この答申が今 回の法改正のべースになっている。

このIT化への対応が法改正の引き金になったこ とは事実であるが, IT化以外にも同時に特許庁を 悩ます問題として, 審査処理問題と国際調和の問 題が顕在化していた。このため, 先行技術文献を 明細書に記載することを義務化して審査処理に対 して出願人の協力を求めること, および出願形式 を国際的な出願様式に合致させるなどの改正が合 わせて行われた。

\section{2. 改正法の5つのポイント}

\section{1. ネットワークを通じたプログラムの流通の 拡大に伴う発明の実施規定の見直し（図1）}

特許権は業として特許発明の「実施」を専有す る権利であり (特許法68条), 実施の内容について は, 特許法 2 条 3 項に「物の発明」と「方法の発明」 「物を生産する方法の発明」に分けて規定されてい る。

改訂審査基準では, プログラムを物の発明とし て特許請求の範囲（請求項）に記載することがで きるとしたが, 審議会ではプログラムを物の発明 とすることが簡単に決まったわけではない。プロ グラムを「物」,「方法」のほかに新たな第3のカテ
ゴリー, 例えば「電子情報によって構成された発 明」といった新カテゴリーを設けるべきという考 え，あるいは実施規定を「物の発明」や「方法の 発明」とに分けるのではなく, 米国特許法271条に 規定されるような「特許発明」の実施として一括 して発明の実施を規定するという案も議論された。 しかし結局, 現行法の物の発明の実施規定を変更 することで対応することが良いとする意見が大勢 を占め, 今回の改正に至ったのである。

この改正法で注目すべきことは,物の発明に「プ ログラム等」を含めたことと, 実施行為の中の「譲 渡等」の規定の中に，「その物がプログラム等であ る場合には，電気通信回線を通じた提供を含む」 ということを明確に定義したことである。

これにより，インターネットを通じてプログラ 厶を送信する行為が特許発明の実施行為に相当す ることが認知されたことになり，プログラムの特 許は権利行使ができないのではないかという改正 前にあった産業界の懸念は払拭された。

次に,「プログラム等」の定義規定を設け，「プ ログラムに準ずるもの」もプログラムと同じよう に権利行使できることを規定したことに，もうひ とつのポイントがあると思われる。この「プログ ラムに準ずるもの」に何が含まれるかというと， 当時,特許庁の工業所有権制度改正審議室長であっ た廣實郁郎氏は,「<座談会 > 特許法・商標法の改 正を語る」（L\&T No16，2002/7）の中で，「プログ ラム以外にいわゆる情報財, 無体物で物の発明と して認められるものは何かといわれれば，今のと ころデータ構造を念頭においているということに なります」と述べている。

プログラムと言えないまでも，コンピュータに 作用して,結果的に仕事をさせることができるデー 夕構造（機能的なデータ構造）は, 物の発明とし

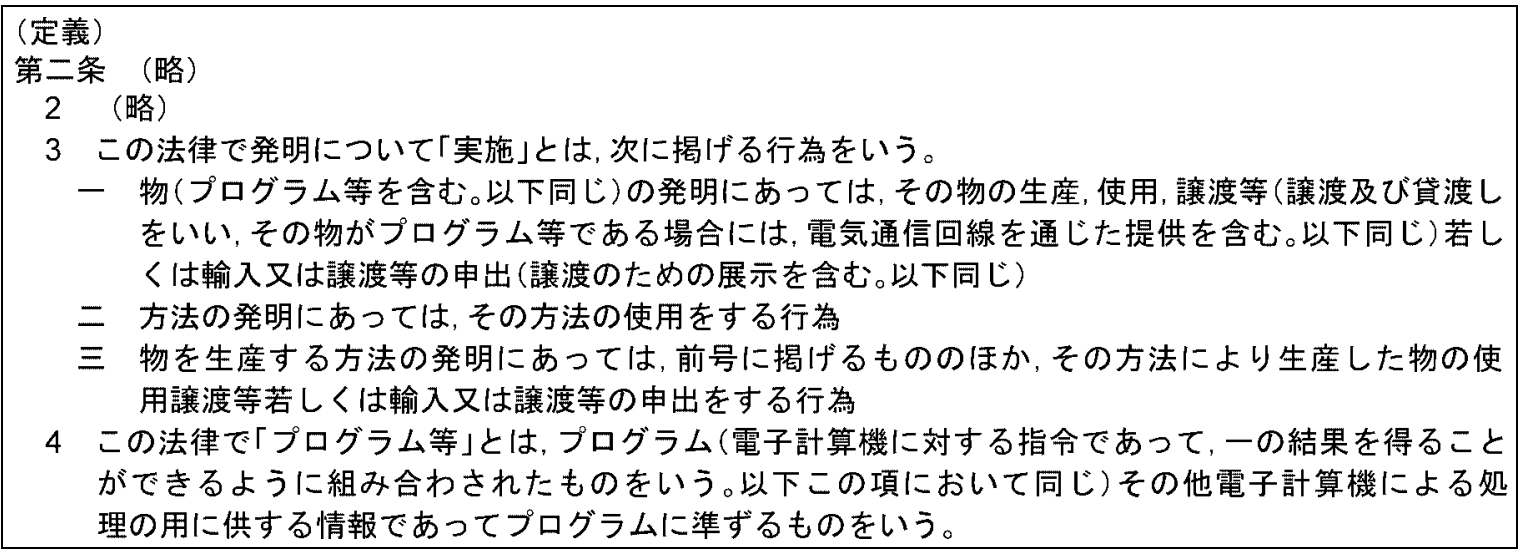


て特許請求の範囲に記載することができるという ことであろう。

しかしながら，この規定はあくまでも実施規定 であって, プログラムは物に限定されるというこ とを決めたものではない。コンピュータに仕事を させるための一連の指令がプログラムであるが, 技術として見た場合には, ソフトウエア関連発明 は, 特許請求の範囲に方法の発明としても記載で きることは言うまでもない。一方, 物の発明とし ても, 大きく分けてクレームの記載には「……装 置」や「……情報処理システム」, 「……というプ ログラムを記録した記録媒体」, あるいは「……プ ログラム」というさまざまな形式のクレーム記載 が認められるということになる。ソフトウエア関 連発明をどのように請求項に書くかは, 出願人の 選択に任せられるのである。

\section{2. ソフトウエア関連発明の拡大と間接侵害規} 定の見直し（図2，図3）

改正前と改正後の条文を比べると一目瞭然であ る。改正前の条文の 1 号と 2 号が改正後は 1 号と 3 号 になり, 新たに2号と4号が追加された。改正法の1 号と3号は客観的要件と言われる。「〜にのみ使用 する物」という規定は厳格に解釈すると, 侵害物 が特許発明だけに使われ，それ以外の製品には使 われないということを意味する。このため侵害者 は, 訴訟において特許発明以外の製品にも利用さ れることを証明すれば間接侵害が免れることにな
り, 間接侵害の成立が否定される判例が多かった。 特にコンピュータの部品としてのモジュールは, 多くの場合, 侵害プログラムにのみ使用されるケー スは少ないため, ソフトウエア部品に関しては, 特許法101条が認められるケースはさらに少なくな ると言われている。なぜならソフトウエアの生産 は, その部品に相当するモジュールが発注元から 下請けへ，下請けから孫受けへというルートで発 注と納品がなされるのが通常である。そして, こ のひとつひとつのモジュールが発注元だけの最終 製品に使われるということはむしろ稀有（けう） であった。このような場合でも, 一定の条件を満 たすならば間接侵害を認めるというのが改正法の 2 号と4号の趣旨であり, 一部主観的要件を加味し た規定になっている。

改正法の 2 号と 4 号も, 特許が物または方法につ いてされている場合であって, その特許を侵害す る物あるいは方法に用いる物を業として生産, 譲 渡等もしくは輸入または譲渡等の申し出をする行 為を間接侵害とする点では, 1 号, 3 号と同じであ る。が, 改正法 2 号と 4 号で新たに設けられた要件 は,「その物が発明による課題解決に不可欠なもの であること（対象物要件）」と,「その発明が特許 発明であること及びその物がその発明の実施に用 いられることを知りながら (主観的要件)」である。 発明の課題解決に不可欠なものとは, 発明の本 質的部分のことと言ってよいだろう。つまり, 特 許請求の範囲に記載されている発明の課題解決に

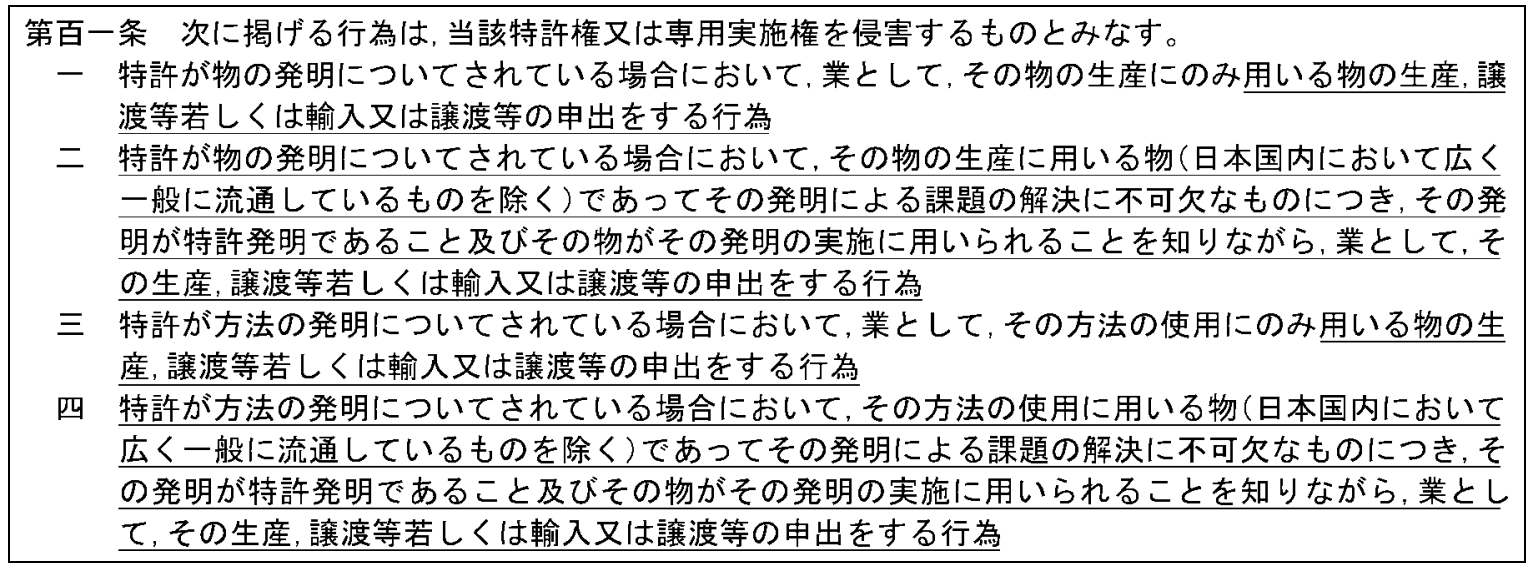

図2 間接侵害関連条文 (改正後)

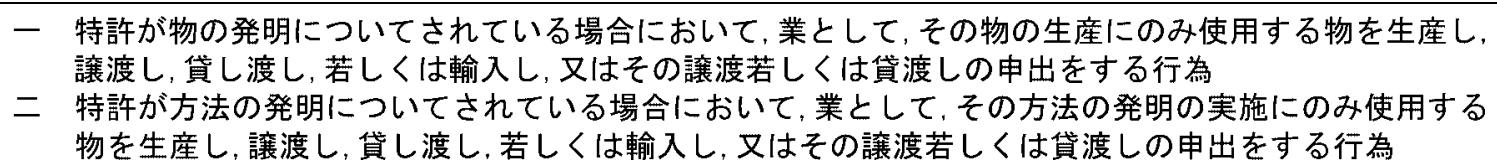

図3 間接侵害関連条文（改正前） 
無関係な末しょう的部分の物を提供しても侵害に はならない。何が本質的かということについては 議論の余地があるが, 発明の特徵部分（先行技術 より貢献した部分と言ってもよいかもしれない) を構成する部品は, 本質的部分すなわち「課題解 決に不可欠なもの」と言えると思う。

「その発明が特許発明であること及びその物がそ の発明の実施に用いられることを知りながら」と いう記述は，正にこの条文が主観的要件と言われ るゆえんである。

そもそも特許法は, 特許請求の範囲に記載され ている事項のすべてを侵害したときに特許権侵害 （直接侵害）と言えるのであって，その意味では， 特許法101条の間接侵害規定は, 本来は侵害でない ものを「侵害と見なす」規定であるから，できる だけ間接侵害にしない方向で条文が構成されてい る。1号，3号の「のみ品」だけを間接侵害とする 規定はそ水を表しているし,改正法2号と4号で「(日 本国内において広く一般に流通しているものを除 く)」というかっこ書きを設けて，ねじやくぎなど の汎用品や普及品を提供することまでも間接侵害 としないことを明記している点もしかりである。

その意味では, 改正法 2 号と 4 号が今後どのよう に扱われるかは興味のあるところだが, 墨意の程 度がどの程度のものかが問題になると思われる。 いずれにせよ, 社会的な常識の線が維持されて運 用されていくことになろう。裁判所の判例が待た れるところである。

\section{3. 先行技術文献情報の開示制度の導入（図4）}

現在，先行技術文献情報が明細書中に開示され ている出願は全体の4割程度であると言われてい る。特許庁の審査官にとって非常に大変な作業は, 先行技術文献のサーチである。明細書の中に先行 技術として説明されている技術であっても，それ を引用例として使う場合には根拠となる文献をサー チして探さなければならない。

改正法の内容は, 出願にかかる発明に関して出 願人が知っている先行技術文献情報を開示するこ とを義務化するものである。そして, 審査官の求 めがあっても十分な開示がされないときは拒絶理 由とすることを明確に規定した。この規定は, 出 願人の有する情報の有効活用を図り, 審査の迅速 化に資することをねらったものである。

ここで,「特許出願の時に知っているもの」とは 具体的に何を意味するのか考えてみたい。文字ど おり読めば, 出願人が出願時に知っている文献が すべて入ってくるわけであるが, 要は出願人といっ ても法人としての出願人が知っている文献すべて を提出することは考えられないから, 本願発明に 関連して, 発明者が過去にした特許出願にかかわ る発明とか, 本願発明に関係して過去に発表した 論文にかかわる発明が該当すると言えよう。

前述のように審査官は, 出願人が明細書中の従 来技術の闌で説明している事項を引用例として利 用したいと思った場合，その開示内容に最も近い 文献を探す必要がある。なぜなら, 出願人が従来

(特許出願)

第三十六条

4 前項第三号の発明の詳細な説明の記載は，次の各号に適合するものでなければならない。

- (略)

二その発明に関係する文献公知発明(第二十九条第一項第三号に揭げる発明をいう。以下この号におい て同じ)のうち、特許を受けようとするものが特許出願の時に知っているものがあるときは，その文献 公知発明が記載された刊行物の名称その他のその文献公知発明に関する情報の所在を記載したもの であること。

（文献公知発明に係る情報の記載についての通知）

第四十八条の七

審査官は, 特許出願が第三十六条第四項第二号に規定する要件を満たしていないと認めるときは, 特許出 願人に対し，その旨を通知し，相当の期間を指定して，意見書を手出する機会を与えることができる。

(拒絶查定)

第四十九条

審査官は特許出願が次の各号のいずれかに該当するときはその特許出願について拒絶をすべき旨の査定 をしなければならない。

一〜四（略）

五 前条の規定による通知をした場合であって，その特許出願が明細書についての補正又は意見書の提出 によってもなお第三十六条第四項第二号に規定する要件を満たすこととならないとき。 
技術といっても，それが公知の技術なのか出願人 （発明者）の認識している先願発明の技術なのか はっきりしないからだ。

特許庁審査官, 特に先端技術分野を審査してい る特許庁の審査官は, 出願の審査に際して, まず 非特許文献ファイル，つまり論文ファイルで発明 者名をキーとして検索を行う (JICST科学技術文献 ファイルはよく使われる)。これで, 発明者の論文 が検索されると, その論文の内容が本願発明の先 行技術に近い場合が多い。拒絶理由通知は, 発明 を構成する前提となる先行技術文献が存在しては じめて起案することができるので, このような作 業が必要とされるのである。

その意味で, 発明者が本願発明の先行技術と認 識している論文名を明細書に開示してあれば, そ の分サーチ時間が短縮され, 審査処理の効率化に つながる。特許庁のねらいはこの点にあると思わ れる。

しかし, 文献名の記載がないからといって, す べての場合に拒絶理由を通知していたのでは二度 手間になる。つまり, 審査官から見れば, 出願の クレームを見ただけで引用例がすぐに出てくるよ うな場合，あるいは，さほどの困難なくサーチを して適切な引用例を見つけ出せる場合には, いち いち明細書に先行技術文献情報が開示されていな いといって出願人に通知をするのは, 逆に審査の 効率ダウンになる。

したがって,この条文はあくまでも, 出願人に 先行技術文献情報を開示することを奨励するため の条文であり, 文献情報の開示のないすべての明 細書に第36条第4項第2号の拒絶理由を通知するこ とはないと私は理解している。とはいえ, 先行技 術文献情報を記載しない常習犯的な出願人には, 容赦なく第48条の7号 (文献公知発明についての記 載についての通知）が適用されるであろうし, そ の応答いかんによっては, 第49条第5号の適用もあ りうると考えられる。

つまり, 拒絶理由となる場合は,

- 審査官からの通知に対して, 手続補正書も意見 書も提出されないとき

・審査官からの通知に対して, 文献を開示する手 続補正書の提出はあったものの, 出願された発 明と関係のない文献公知発明しか開示しなかっ たとき

・審査官からの通知に対して, 意見書で不開示の 理由を説明しているが,それが十分な説明になっ ていないとき
である。

出願人サイドからこの規定を見るならば，特許 出願するにあたり, 自らが調査した発明と関連す る文献は積極的に明細書中に開示することが求め られることになる。特に, 発明者の論文がある場 合には，その論文に記載されている技術をべース に明細書の従来技術の説明および本願発明の課題 を説明していくことが必要とされよう。

\section{4. 出願様式の国際調和}

この改正は,一言で言えば「明細書からの特許 請求の範囲の分離」である。現在, 特許協力条約 (Patent Cooperation Treaty PCT) においては, 国際出 願の電子化を検討しているが, その際に用いられ る出願のフォーマットは, 明細書と特許請求の範 囲が分離されている。電子出願前の現在でも明細 書と特許請求の範囲は分離されているのだが, 電 子出願になると, この出願フォーマットで国際間 のデータのやり取りが行われる。つまり,この出 願フォーマットが世界標準となることが予想され るわけである。

わが国においても，2003年7月を目途に国際出願 の電子化が検討されており, そのための準備とし てPCTに定める出願様式と整合をとる必要があっ た。つまり明細書から特許請求の範囲を分離し, 明 細書から独立した願書の添付書類としたのである。 なお現在, 日本出願に基づいてPCT出願をする 場合には, 特許請求の範囲を明細書から独立させ て出願様式を変更しているのであるが, 特許出願 の方式を国際出願に整合させることは, 出願様式 の変更に伴うユーザの負担を軽減することになり， この改正事態に反対を唱える人はいないと思われ る。なお, 特許法の条文上は「明細書」という記 載を「明細書, 特許請求の範囲」と分離して記載 することになり, 改正条文数はきわめて多くなっ ている。

\section{5. РCT出願における国内書面提出期限の延長}

まず, 改正前の制度であるが, РCT出願を国内 段階へ移行する場合の国内書面の提出期限につい ては, 国際予備審査を請求するかしないかで2段階 に分かれていた。すなわち, 国際予備審査を請求 しない場合は, 優先日から20か月以内, 国際予備 審査を請求する場合は優先日から 30 月以内となっ ていた。

このため出願人の中には, 国内段階への移行期 限を延ばす目的で不必要な予備審査請求を行う者 
もあった。

また, 外国語で提出されたPCT出願は, 国内段階 に入る際にその翻訳文を国内段階への移行期間内 に提出しなければならなかった。

2001 年にWIPOで開催されたPCT同盟総会では, PCTの国内移行期間を国際予備審査請求いかんに かかわらず，一律 30 月に延長することが決議され た。今回の改正はこのWIPOの決議を受けたもので ある。また, 国内段階への移行の判断は, 移行期限 ぎりぎりまで延ばされることが多いので, 翻訳文 の提出が国内書面と同時に求められると, 拙速な 翻訳文が提出されるおそれがある。このような翻 訳文が審査にかかると, 明細書記載不備の拒絶理 由通知の原因にもなり, かえって審査処理の遅延 をもたらすことになる。このため, 国内段階移行 時から2か月間,翻訳文の提出に猶予期間を与えた。

これによって国内代理人も，翻訳文作成の期間 が2か月間確保できるので, 質の高い翻訳文を作成 することができると期待される。

\section{6. 施行時期について}

今回の改正特許法は, その周知期間, 特許庁内 の情報システム整備に要する期間, 政省令の策定 に要する期間等を踏まえ, 次の3段階で施行するこ とになっている。

（1）第一段階：法律公布（2002年4月17日）から6か 月以内の政令指定日から

- 実施行為関連規定（施行日後の行為に適用）

- 先行技術文献開示規定 (施行日後の出願から適用)

- PCT出願国内書面提出期間の延長 $(20$ か月 $\rightarrow 30$ か月）(施行日に提出期限内の出願にも適用)

- PCT出願翻訳文提出期間の延長（施行日に提出 期限内の出願にも適用)

（2）第二段階：法律公布（2002年4月17日）から1年 以内の政令指定日から

·間接侵害規定

間接侵害規定は裁判規範であり，権利の単なる 明確化ではなく, 拡充となるため, 説明会等を 行う十分な周知期間を確保する必要がある。な お, 間接侵害規定中の実施行為関連規定も同じ 期日をもって施行することにしたのである。

（3）第三段階：法律公布（2002年4月17日）から1年 6か月以内の政令指定日から

・明細書の様式変更（施行日後の出願に適用）

特許庁の情報システムの変更が2003年7月に予定 されており, そのシステムの変更に合わせて施 行することにした。

\section{3. 今後の検討事項}

今回の改正法には盛り込まれなかったが, 審議 会で議論された問題のひとつに, 発明の定義規定 の問題がある。特許法はその第2条第1項に「発明 とは自然法則を利用した技術的思想の創作のうち 高度のもの」という定義規定を設けている。審議 会で議論されたのはビジネス方法特許に関連して, 特許庁が審査基準で第2条に定義された発明となる こと（これを「発明の成立性」と言う）を法改正 なしで保証されるかということである。

「自然法則を利用した」という文言はそもそも必 要であろうかという疑問も提起された。しかし審 査基準は, この定義規定の解釈を変えることで, コ ンピュータ・プログラム自体までも発明の成立性 があるとしてきた経緯がある。今回の改正でこの 定義規定まで変えるとなると, ビジネス方法その ものまで特許法の保護対象になるのではないかと いう懸念が多くの委員から出され, 結果として定 義規定の変更は見送られた。また，この定義規定 の問題は, 国際的調和を図ることが重要であり, 現 在WIPOで議論されている実体ハーモ条約の検討の 結果を踏まえて,再度審議会で議論することとした。

次の問題は, ネットワークとサーバを利用した ビジネス方法特許の実施行為に関連して, クライ アント, サーバ管理者, プログラム作成者, ネット ワーク管理者等がそれぞれ異なった者である（通 常の場合はそうである）ときの, プログラム特許の 侵害が成立するかという問題である。この問題も 特許法の一部改正だけで解決できないネットワー ク社会全体に関連する問題を含んでおり, 継続審 議ということになった。業として実施していない クライアントが多い中で, 特にサーバが外国にあ り,クライアントが日本にいるような場合に, 共同 不法行為が成立するかということも含め, 国際的 な検討が待たれるところである。また,このような ケースでは国際裁判管轄の問題にも及ぶ話になる。

このように, 今回の特許法改正で必ずしもIT社 会に完全に対応した十分な制度が完成したという ことではないと思うが, ネットワーク社会および IT社会に対応した一応の整備がなされたと言うこ とができると思う。しかし言うまでもなく,グロー バルな社会においては, 特許制度といえども 1 人 1 か国だけが世界の潮流と外れてよいものではない。 今後はさらにWIPO等の国際的なハーモナイゼー ション議論を踏まえて, 国際的に整合性のとれた 制度改正を行っていく必要があろう。 